Prosiding Seminar Nasional Teknologi Informasi dan Kedirgantaraan : Transformasi Teknologi untuk Mendukung Ketahanan Nasional, Yogyakarta, 13 Desember 2018

SENATIK 2018, Vol. IV, ISBN 978-602-52742-0-6

DOI: http://dx.doi.org/10.28989/senatik.v4i0.232

\title{
DESIGN AND ANALYSIS THE STRENGTH OF THE STRUCTURE FIXED WING VERTICAL TAKE OFF-LANDING UAV Djarot Wahju Santoso ${ }^{1}$, Aditya Nurcholis Putra ${ }^{2)}$ \\ ${ }^{1,2}$ Program Studi Teknik Penerbangan \\ Sekolah Tinggi Teknologi Adisutjipto \\ Jl. Janti Blok R Lanud Adisutjipto Yogyakarta \\ Email: 1djarot_wahyu84@yahoo.com
}

\begin{abstract}
To respond to traffic conditions in the city traffic jam so as to resolve the density it is necessary to observe these conditions which are monitored at all times. For this reason, it is necessary to design UAV (Unmanned Aerial Vehicle) that is capable of flexible maneuvering, which can take off and land vertically and move quickly to reach traffic in different places. The stages of research for designing fixed wing VTOL aircraft are carried out determining the geometry of the aircraft as the desired criteria, the analysis stage by $3 D$ modeling with CATIA software. Simulation of structural analysis in the form stress and calculating the Margin of Safety from this design. The results of the aircraft design have $1.32 \mathrm{~m}$ fuselage length, $1.71 \mathrm{~m}$ wing span and aircraft weight $2.865 \mathrm{~kg}$. The results of the analysis show that the aircraft structure is safe in cruise and vertical take-off load.
\end{abstract}

Keyword: Design, VTOL UAV, structure analysis

Abstrak

Guna merespon kondisi lalu lintas di tengah kota yang mengalami kemacetan sehingga untuk menguraikan kepadatan perlu pengamatan kondisi tersebut yang terpantau setiap saat. Untuk itu dibutuhkan rancangan pesawat UAV (Unmanned Aerial Vehicle) yang mampu melakukan manuver fleksibel yaitu bisa lepas landas dan mendarat secara vertikal dan bergerak cepat untuk menjangkau lalu lintas di tempat yang berbeda. Tahapan penelitian perancangan pesawat UAV Fixed Wing VTOL dilakukan melalui penentuan geometri pesawat sesuai dengan kriteria yang diinginkan, tahap analisis dengan melakukan pemodelan 3D dengan software CATIA. Simulasi analisis struktur berupa luaran tegangan dan menghitung Margin of Safety dari rancangan tersebut. Hasil rancangan pesawat tersebut mempunyai panjang fuselage $1,32 \mathrm{~m}$, bentang sayap $1,71 \mathrm{~m}$ dan berat pesawat 2,865 $\mathrm{kg}$. Hasil analisis menunjukkan struktur pesawat dinyatakan aman pada beban terbang jelajah dan vertical take off.

Kata Kunci; Perancangan, UAV VTOL, analisis struktur

\section{Pendahuluan}

Pesawat Terbang Tanpa Awak sering disebut Unmanned Aerial Vehicle (UAV) merupakan pesawat yang terbang tanpa pilot yang menyertai di pesawat selama penerbangan. $U A V$ digunakan untuk penginderaan jarak jauh, penghubung alat komunikasi, serta pemantauan kondisi bencana alam. $U A V$ dapat dilengkapi kamera guna merekam suatu objek yang dijadikan data untuk pemantauan.

Pesawat RC (Remote Control) Fixed Wing yang umum membutuhkan landasan relatif panjang dan tidak bisa melakukan take-off dan pendaratan secara vertikal (VTOL) serta kemampuan manuvernya di sekitar objek terbatas. Disisi lain pesawat RC Rotary Wing 
(Quadcopter) memiliki kemampuan VTOL tetapi kecepatan lambat serta konsumsi energinya lebih besar dibandingkan pesawat RC Fixed Wing.

Untuk merespon kondisi lalu lintas di tengah kota yang sering kali mengalami kemacetan sehingga untuk menguraikan kepadatan tersebut perlu pengamatan kondisi lalu lintas yang bisa terpantau setiap saat. Untuk itu dibutuhkan $U A V$ yang dapat melakukan manuver fleksibel yaitu bisa lepas landas (take off) dan mendarat (landing) secara vertikal dan bergerak cepat untuk menjangkau kondisi lalu lintas di tempat yang berbeda. Pesawat ini adalah suatu pesawat UAV Fixed Wing yang mempunyai kemampuan seperti Rotary Wing (Quadcopter) yang dikenal dengan UAV Fixed Wing VTOL yang dilengkapi kamera. Fokus penelitian ini adalah untuk merancang pesawat UAV Fixed Wing yang mampu melakukan take off maupun landing secara vertikal yang membutuhkan landasan pendek serta mampu melakukan manuver fleksibel sehingga dapat dimanfaatkan untuk memantau kondisi lalu lintas.

Penelitian pesawat UAV Vertical Take off dan Landing kebanyakan dilakukan dengan menggunakan konfigurasi rotary wing yang mempunyai 4 rotor (quadcopter), 6 rotor (hexacopter) maupun multi rotor. Sedangkan yang menggunakan konfigurasi fixed wing baru belakangan yang dipublikasikan dan dikembangkan. Perancangan pesawat VTOL fixed wing yang mempunyai 3 rotor mampu diputar pada sudut $90^{\circ}$ sehingga bisa terbang vertikal maupun terbang cruise [1]. Pada perancangan tersebut dilakukan perhitungan geometri dan pemodelan pesawat menggunakan CATIA V5. Rancangan tersebut mampu membawa muatan $1 \mathrm{~kg}$, dengan jarak tempuh $1 \mathrm{~km}$ serta endurance terbang stabil selama 16 menit

Penelitian pesawat yang sejenis namun rotor yang digunakan berjumlah 4 juga dapat diputar pada sudut $90^{\circ}$ [2]. Hasil rancangannya adalah pesawat yang mampu melakukan lepas landas secara vertikal dan terbang cuise. Sasaran rancangan adalah berat total pesawat $5 \mathrm{~kg}$, dengan dimensi wing span 1,5 $\mathrm{m}$ dan mampu terbang dengan kecepatan $25 \mathrm{~m} / \mathrm{s}$.

Kedua peneliti di atas telah merancang geometri dan pemodelan 3D namun belum dilakukan analisis kekuatan struktur hasil rancangannya, penelitian kali ini difokuskan pada menentukan geometri pesawat sekaligus melakukan analisis kekuatan struktur dengan metode FEM (Finite Element Method).

\section{Metodologi Penelitian}

Tahapan penelitian yang dilakukan dapat dijelaskan sebagai berikut:

1. Studi Literatur

Pada tahap ini dilakukan pemahaman pada referensi atau sumber pustaka yang berkaitan dengan topik penelitian seperti buku, jurnal, serta sumber referensi yang lain.

2. Proses Perancangan

Pada tahap ini dilakukan proses penentuan geometri pesawat UAV Fixed Wing Vertical take off dan Landing yang sesuai dengan kriteria yang diinginkan.

3. Analisis

Pada tahap ini dilakukan proses analisis kekuatan struktur pesawat UAV Fixed Wing Vertical Take Off dan Landing. Langkah analisis dilakukan dengan melakukan pemodelan yang telah ditentukan geometrinya melalui proses perancangan dengan software CATIA versi V5R21. Dilanjutkan melakukan simulasi menggunakan metoda FEM (Finite Element Method) untuk menentukan output tegangan Von Mises sekaligus menghitung Margin of Safety dari rancangan tersebut.

\subsection{Penentuan $D R \& O$ Pesawat UAV Fixed Wing VTOL}

Dalam melakukan perancangan pesawat perlu ditentukan batasan-batasan dan tujuan yang ingin dicapai atau $D R \& O$ (Design Requirement And Objective) sebagai berikut:

1. Misi pesawat adalah untuk pemantauan lalu lintas di suatu daerah. 
2. Kecepatan terbang jelajah pesawat untuk pengambilan gambar dengan kamera tidak melebihi $17 \mathrm{~m} / \mathrm{s}$.

3. Berat maksimum keseluruhan pesawat tidak lebih dari $3 \mathrm{Kg}$.

4. Bentang sayap (span) tidak melebihi $1,7 \mathrm{~m}$ berdasarkan rata-rata pesawat pembanding.

5. Kategori pesawat Fixed Wing yang mampu melakukan take off dan landing secara vertikal (VTOL).

6. Ketinggian jelajah pesawat $150 \mathrm{~m}$ di atas permukaan laut.

\subsection{Penentuan Konfigurasi}

Pemilihan konfigurasi pesawat yang dirancang adalah sebagai berikut:

1. Konfigurasi sayap

Untuk memberikan ratio Lift/Drag yang besar, kemudahan proses manufaktur, penggunaan untuk kecepatan rendah konfigurasi sayap pesawat dipilih bentuk rectangular, dengan posisi sayap berada di atas badan pesawat (high wing).

2. Konfigurasi ekor

Konfigurasi ekor yang dipilih adalah jenis conventional tail, karena secara umum jenis ini banyak digunakan pada pesawat terbang dan lebih stabil saat dioperasikan.

3. Konfigurasi posisi engine

Dengan pertimbangan meminimalkan kerusakan saat landing dan kebutuhan tingkat kestabilannya yang bagus dipilih konfigurasi engine jenis pusher dimana engine diletakkan di belakang badan pesawat.

\subsection{Perkiraan Berat Pesawat}

Dalam menentukan perkiraan perancangan berat pesawat dilakukan dengan melakukan regresi antara berat WTO dan wing span dari pesawat pembanding yang diperoleh dari tabel berikut:

Tabel 1. Pesawat pembanding $U A V$

\begin{tabular}{|l|c|c|c|c|c|}
\hline \multirow{2}{*}{ Aspek } & \multicolumn{5}{|c|}{ Pesawat Pembanding } \\
\cline { 2 - 6 } & Kapetair & $\begin{array}{c}\text { Foxtech } \\
\text { Nimbus }\end{array}$ & Chrysaor & $\begin{array}{l}\text { Krossblade } \\
\text { Skyprowler }\end{array}$ & POGL018 \\
\hline WTO (Kg) & 6,5 & 2,8 & 3,5 & 2 & 1,5 \\
\hline Length $(\mathrm{m})$ & 1,55 & 1,3 & 1,4 & 0,6 & - \\
\hline Span $(\mathrm{m})$ & 3,3 & 1,8 & 1,8 & 0,9 & 1,16 \\
\hline Vcruise $(\mathrm{m} / \mathrm{s})$ & 18 & 35 & - & 29 & - \\
\hline Vstall $(\mathrm{m} / \mathrm{s})$ & 8 & 9 & - & & 8 \\
\hline
\end{tabular}

Span Vs WTO

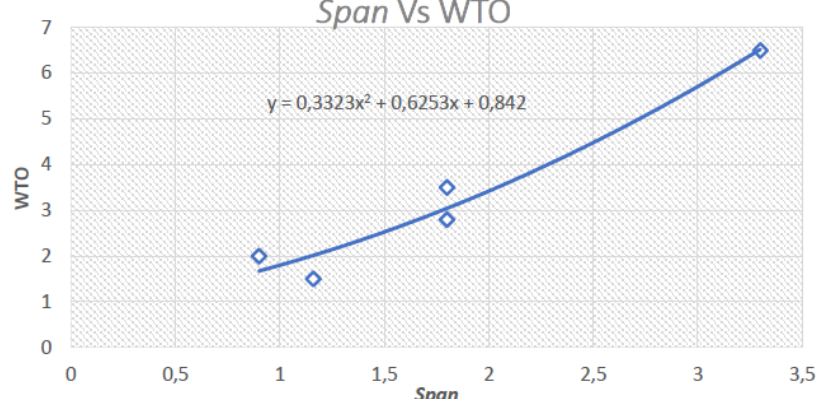

Gambar 1. Grafik WTO Vs Span

Berdasarkan grafik tersebut diperoleh persamaan berikut:

$$
y=0,3323 x^{2}+0,6253 x+0,842
$$

Berat pesawat (y) diperoleh dengan memasukkan nilai wing span (x) sebesar 1,7 $\mathrm{m}$ sehingga diperoleh berat pesawat pada saat take off (WTO) adalah 2,865357 kg. 


\subsection{Penentuan Geometry Sizing}

1. Fuselage

Penentuan panjang badan pesawat menggunakan data pesawat pembanding yang ada di tabel 1. dengan menggunakan regresi polinomial orde 2 diperoleh persamaan berikut:

$$
\mathrm{y}=-0,0074 \mathrm{x}^{2}+0,1311 \mathrm{x}+1,0143
$$

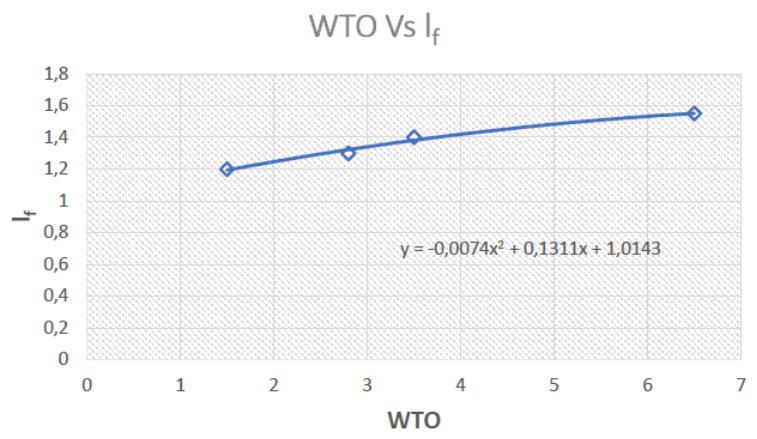

Gambar 2. Grafik Span (lf) Vs WTO

Panjang fuselage didapat dengan memasukkan nilai $(\mathrm{x})=2,865357$ ke dalam persamaan tersebut sehingga diperoleh $1,32 \mathrm{~m}$.

2. Wing

Untuk penentuan geometri sayap diperlukan perhitungan wing loading terlebih dahulu sesuai dengan persamaan berikut [3]:

$\left(\frac{W_{T O}}{s}\right)=0.5 \rho$ Vstall $^{2}$ Clmax

Diasumsikan kecepatan stall pesawat UAV VTOL $9 \mathrm{~m} / \mathrm{s}, \rho$ pada kondisi sea level adalah $1,225 \mathrm{~kg} / \mathrm{m}^{3}$. Sedangkan nilai Clmax diambil 1,5 untuk sayap tanpa flap berdasarkan [3]. Nilai CLmax sayap adalah 90\% dari Clmax airfoil, sehingga diproleh 1,35. Masukkan parameter tersebut ke dalam persamaan (1)

$$
\frac{W}{S}=0,5 \times(1.225) \times(9)^{2}(1,35)=66,97688 \frac{\mathrm{N}}{\mathrm{m}^{2}}
$$

Bentuk sayap rectangular dengan nilai $\lambda=1$, dipilih aspect rasio $(\mathrm{AR})=7$ sehingga dimensi luas permukaan sayap $\left(S_{W}\right)$ dihitung menggunakan persamaan berikut:

$$
\begin{aligned}
& S_{W}=\frac{W}{W / S} \\
& S_{W}=\frac{28,0805}{66,9769} \quad S_{W}=0,4193 \mathrm{~m}^{2}
\end{aligned}
$$

Span sayap:

$$
\begin{aligned}
& b w=\sqrt{\operatorname{AR\times } S_{W}} \\
& b w=\sqrt{7 \times 0,419257} \quad b w=1,7131 \mathrm{~m}
\end{aligned}
$$

Chord sayap:

$$
\begin{aligned}
C w & =\frac{S_{W}}{b w} \\
C w & =\frac{0,4193}{1,7131} \quad C w=0,2447 \mathrm{~m}
\end{aligned}
$$

\section{Tail Moment arm}

Menurut [3] tail moment arm adalah $65 \%$ dari panjang fuselage (lf)

$$
\mathrm{L}_{\mathrm{T}}=65 \% \text { lf }
$$




\section{Tail}

$$
\mathrm{L}_{\mathrm{T}}=65 \% \times 1,32=0,86385 \mathrm{~m}
$$

Untuk menentukan dimensi ekor pesawat perlu diketahui terlebih dahulu nilai Vertical tail volume coefficient $\left(C_{V T}\right)$ dan Horizontal tail volume coeficient $\left(C_{H T}\right)$. Berdasarkan [3] nilai koefisien pesawat yang dirancang menggunakan $C_{H T} 0,5$ dan $C_{V T} 0,04$. Sehingga dimensi tail ditentukan dengan mensubstitusikan kedua coefficient tersebut ke dalam persamaan berikut (5) dan (6):

$$
\begin{aligned}
& S_{H T}=\frac{C_{H T} c_{W} S_{W}}{L_{T}} \\
& S_{V T}=\frac{c_{V T} c_{W} S_{W}}{L_{T}}
\end{aligned}
$$

Dimana:

$$
\begin{array}{lc}
\mathrm{S}_{\mathrm{VT}}=\text { Luas vertical tail } & \mathrm{bw}=\text { Wing } \text { span } \\
\mathrm{S}_{\mathrm{HT}}=\text { Luas horizontal tail } & \mathrm{SW}=\text { Wing } \text { area } \\
\mathrm{L}_{\mathrm{T}}=\text { Tail moment arm lengh } &
\end{array}
$$

Luas horizontal stabilizer diperoleh sebagai berikut:

$$
S_{H T}=\frac{0,5(0,244732)(0,419257)}{0,86385}=0,059389 \mathrm{~m}^{2}
$$

Dengan menggunakan persamaan yang sama pada sayap, untuk horizontal stabilizer dengan aspect ratio $=4$ dan tapper ratio=1 maka diperoleh panjang span $0,487395 \mathrm{~m}$ dan chord sebesar $0,121849 \mathrm{~m}$.

Luas vertical stabilizer diperoleh sebagai berikut:

$$
S_{V T}=\frac{0,04(0,419257)(1,713125)}{0,86385}=0,033258 \mathrm{~m}^{2}
$$

Untuk perhitungan panjang span dan chord sedikit berbeda karena vertical stabilzer menggunakan tapper ratio 0,45 dan aspect ratio 1,65. Perhitungan dilakukan dengan persamaan berikut:

$$
\begin{aligned}
& b_{V T}=\sqrt{A R_{V T} \times S_{V T}} \\
& b_{V T}=\sqrt{1,65 \times 0,033258} \quad b_{V T}=0,234254 \mathrm{~m}
\end{aligned}
$$

\subsection{Perhitungan Margin of Safety (MS)}

Batas keamanan (Margin of Safety) didefinisikan sebagai suatu besarnya ukuran kemampuan atau kapasitas yang masih tersedia dalam suatu struktur untuk menerima beban statik secara aman. Bentuk umum persamaan margin of safety $(M S)$ yang mengacu pada tegangan adalah [4]:

$$
\text { Margin of Safety }(M S)=\frac{\sigma_{\text {all }}}{\sigma_{\text {app }}}-1
$$

Dimana: $\sigma_{a p p}$ (applied stress $)=$ Tegangan yang terjadi pada struktur

$$
\sigma_{\text {all }}(\text { allowable stress })=\text { Tegangan yang diijinkan }
$$

Struktur dinyatakan aman bila nilai $M S$ berharga positif.

\subsection{Pemodelan pesawat UAV Fixed Wing VTOL}

Pembuatan model 3 dimensi pesawat tanpa awak UAV VTOL dilakukan pada hasil perhitungan rancangan yang telah dihitung sebelumnya. Pembuatan model dilakukan menggunakan software CATIA V5R21. Model UAV VTOL terdiri dari fuselage, wing, tail, dan tailboom seperti pada gambar berikut: 


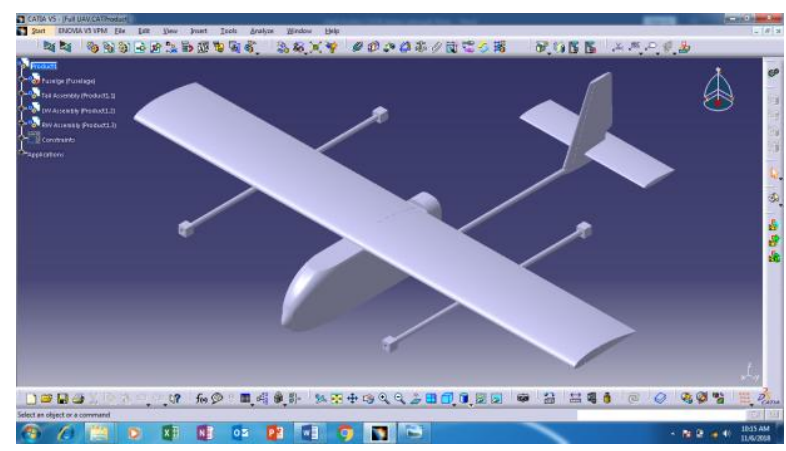

Gambar 3. Hasil pemodelan pesawat UAV Fixed Wing VTOL

Kondisi Pembebanan yang diterapkan pada UAV VTOL ada 3 macam:

- Kondisi pada terbang jelajah

- Kondisi pada vertical take off menggunakan 4 motor pada batang VTOL

- Kondisi terbang jelajah, beban diterapkan pada horizontal stabilizer

- Pada kondisi terbang jelajah pesawat akan mengalami gaya angkat sebesar berat pesawat dikalikan load faktornya sebesar 3,8 referensi [5].
$\mathrm{L}=\mathrm{nW}$
$\mathrm{L}=3,8(2,85 \mathrm{~kg})\left(9,8 \mathrm{~m} / \mathrm{s}^{2}\right)$
$\mathrm{L}=106,134 \mathrm{~N}$

Analisis pembebanan dilakukan pada setengah sayap sehingga beban yang terjadi adalah:

$\mathrm{L}=106,134 \mathrm{~N}(0,5) \quad \mathrm{L}=53,067 \mathrm{~N}$

- Pada pembebanan take off pesawat akan mengalami pembebanan pada ke empat engine mount. Untuk satu engine mount beban yang terjadi seperempat dari gaya angkatnya.

$\mathrm{L}=106,134 \mathrm{~N}(0,25) \quad \mathrm{L}=26,5335 \mathrm{~N}$

- Untuk beban pada tail dilakukan pada kondisi terbang jelajah yang diterapkan pada horizontal stabilizer [6]:

$L_{t}=\frac{M_{a c}}{l_{t}+a}+\frac{a \cdot m g}{l_{t}+a}$

$C_{m_{\text {nR }}}=0,592$ koefisien diperoleh dari data sayap menggunakan software XFLR5

$\bar{c}=0.244473 \mathrm{~m}, S=0,419257 \mathrm{~m}^{2}, \mathrm{~V}=18 \mathrm{~m} / \mathrm{s}^{2}, \rho=1,207 \mathrm{~kg} / \mathrm{m}^{3}$

$M_{a c}=\frac{1}{2} \rho V^{2} S C_{m_{a c}} \bar{c} M_{a c}=\frac{1}{2}(1,207)(17)^{2}(0,419257)(-0,592)(0.244473)=-10.58 \mathrm{~N}$

$\mathrm{a}=0.087 \mathrm{~m}$ jarak dari pusat tekanan ke Cg pesawat

$l_{t}=0.568 \mathrm{~m}$ jarak dari $\mathrm{Cg}$ pesawat ke Cg horizontal stabilizer

$L_{t}=\frac{-10,58}{(0.568+0,087)}+\frac{0.087 \cdot(2,85)(9,8)}{(0.568+0,087)} \quad L_{t}=-12,43 \mathrm{~N}$

Tabel 2. Data penggunaan material pada pesawat UAV VTOL

\begin{tabular}{|l|l|c|c|}
\hline Komponen & Nama Material & Tegangan luluh (MPa) & Jenis Material \\
\hline Wing, fuselage, tail & Styrofoam & 0,641 & Isotropik \\
\hline $\begin{array}{l}\text { Stringer wing, } \\
\text { Stringer tail, batang VTOL }\end{array}$ & Carbon & 867 & Isotropik \\
\hline Engine mount & Plywood & 13,3 & Isotropik \\
\hline
\end{tabular}




\section{Hasil dan Pembahasan}

\subsection{Analisis struktur assembly sayap pada beban kondisi terbang jelajah}

Pada pembebanan kondisi terbang jelajah, struktur setengah sayap dibebani gaya angkat 53,067 N, clamp diletakkan pada ujung root sayap. Tampilan defleksi dan tegangan maksimum Von Mises pemodelan struktur UAV Fixed Wing VTOL adalah sebagai berikut:

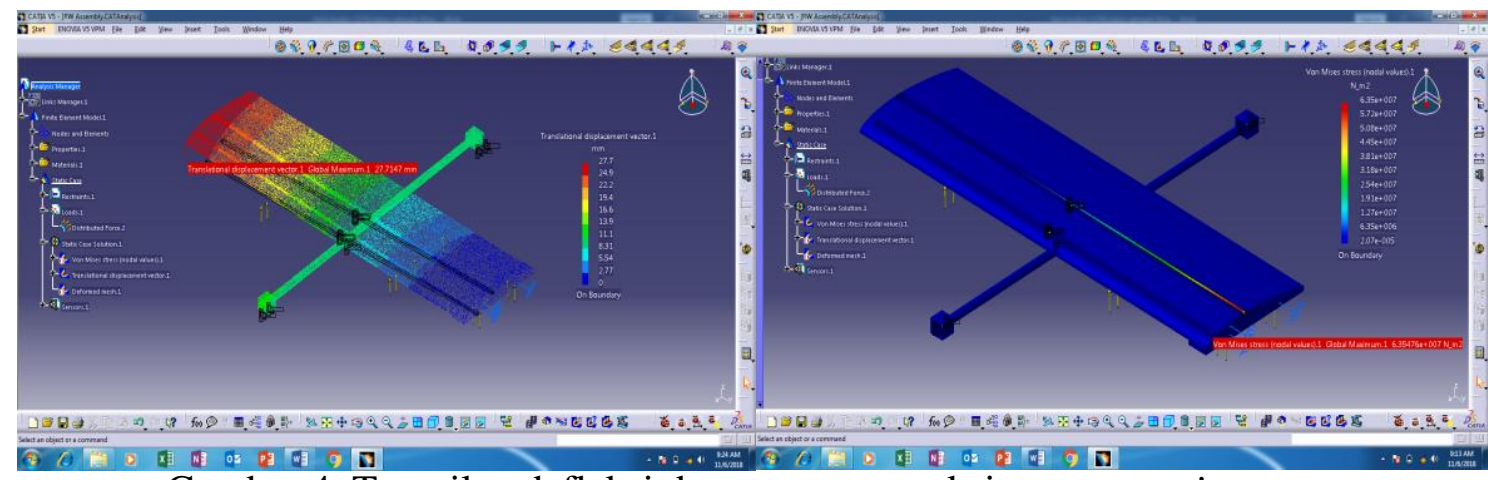

Gambar 4. Tampilan defleksi dan tegangan maksimum von mises.

Besar defleksi maksimum adalah $27,715 \mathrm{~mm}$ terletak pada bagian tip sayap hal ini terjadi karena besar gaya maksimum terjadi pada bagian tip. Nilai tegangan maksimum $6,355.10^{7} \mathrm{~Pa}$ terletak pada struktur stringer bagian bawah tepatnya pada ujung root sayap. Hal ini disebabkan tegangan bending maksimum sayap yang ditumpu pada root akan mempunyai momen bending maksimum pada bagian root sayap.

Sedangkan perhitungan nilai Margin of Safety $(M S)$ pada stringer adalah sebagai berikut:

$$
\mathrm{MS}=\frac{1,08 \cdot 10^{9} \mathrm{~Pa}}{6,355 \cdot 10^{7} \mathrm{~Pa}}-1=0,661
$$

Nilai tegangan maksimum dan besar $M S$ pada masing-masing komponen sebagai berikut.

Tabel 3. Nilai tegangan maksimum dan $M S$ pada kondisi terbang jelajah

\begin{tabular}{|l|c|c|c|}
\hline \multicolumn{1}{|c|}{ Part } & $\begin{array}{c}\text { Tegangan } \\
\text { Maksimum (Pa) }\end{array}$ & $\begin{array}{c}\text { Yield } \\
\text { Strength }(\text { Pa) }\end{array}$ & Margin of Safety \\
\hline Sayap & $2,734.10^{5}$ & $6,41.10^{5}$ & 1,345 \\
\hline Batang VTOL & $8,239.10^{6}$ & $8,67.10^{8}$ & 104,231 \\
\hline Stringer atas & $6,036.10^{7}$ & $8,67.10^{8}$ & 13,364 \\
\hline Stringer bawah & $6,355.10^{7}$ & $8,67.10^{8}$ & 12,643 \\
\hline Engine mount depan & $2,093.10^{-3}$ & $1,33.10^{7}$ & $6,355.10^{9}$ \\
\hline Engine mount belakang & $1,981.10^{-3}$ & $1,33.10^{7}$ & $6,714.10^{9}$ \\
\hline
\end{tabular}

Pembebanan kondisi terbang jelajah pada struktur fuselage beban gaya angkat 106,134 N diterapkan pada kontur fuselage, clamp diletakkan di sambungan fuselage dengan sayap. Besar tegangan maksimumnya adalah $2,451.10^{4} \mathrm{~Pa}$ (gambar 6), sedangkan nilai $M S$ nya 25,153 .

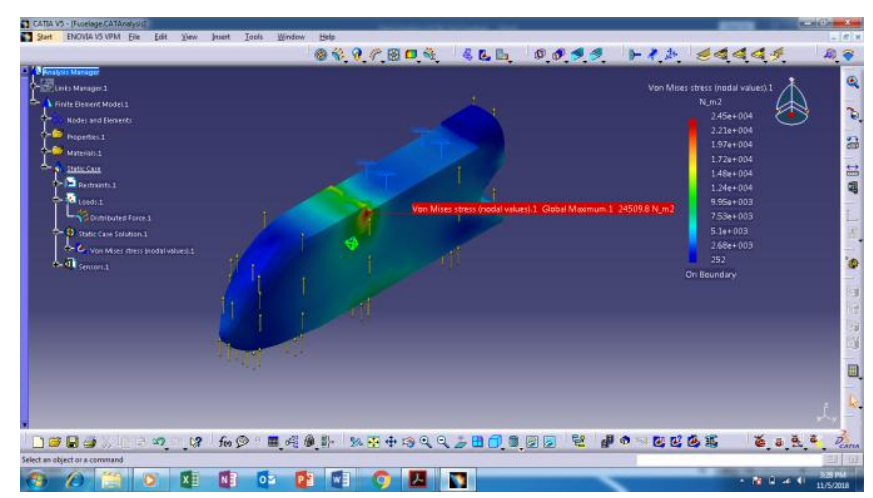

Gambar 5. Tampilan Tegangan maksimum pada fuselage 


\subsection{Analisis struktur assembly sayap pada beban kondisi vertical take off}

Kondisi pembebanan vertical take off dilakukan dengan memberi beban 26,5335 N pada kedua engine mount, posisi clamp diletakkan pada bagian root sayap. Nilai tegangan maksimum $4.719 .10^{7} \mathrm{~Pa}$ terletak pada stringer atas (gambar 6). Hal ini terjadi karena beban yang diterapkan pada ujung batang VTOL akan diruskan ke bagian sayap. Bagian sayap yang mampu menahan beban bending adalah bagian stringer. Pada kasus ini stringer atas mengalami beban tekan yang berlebih (diameter dalam $4 \mathrm{~mm}$ ) dibandingkan dengan batang VTOL (diameter $16 \mathrm{~mm}$ ). Beban tekan tersebut memungkinkan terjadi kondisi buckling pada stringer atas. Besar nilai MS-nya 17,373 sedangkan nilai defleksi maksimum 17,825 mm terjadi pada engine mount bagian belakang.

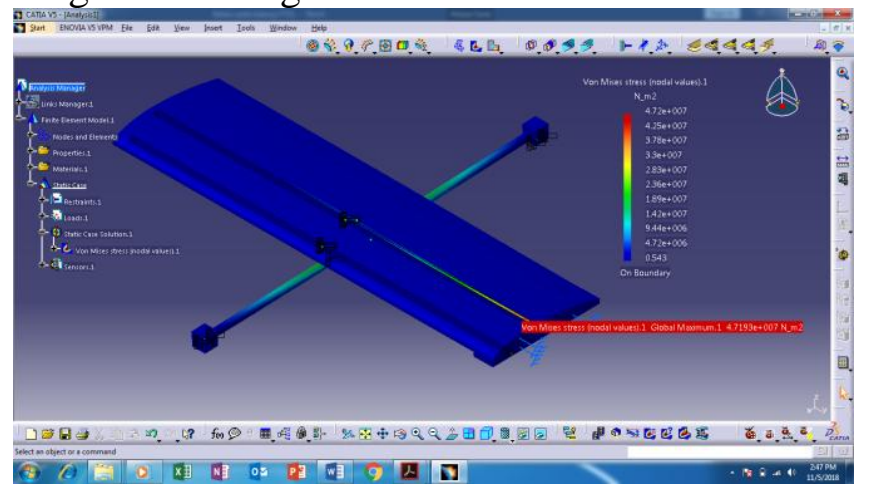

Gambar 6. Tegangan maksimum Von mises pada beban vertical take off

Tabel 4. Nilai tegangan maksimum dan $M S$ pada beban vertikal take off

\begin{tabular}{|l|c|c|c|}
\hline \multicolumn{1}{|c|}{ Part } & $\begin{array}{c}\text { Tegangan } \\
\text { Maksimum (Pa) }\end{array}$ & $\begin{array}{c}\text { Yield } \\
\text { Strength (Pa) }\end{array}$ & Margin of Safety \\
\hline Sayap & $1,905.10^{5}$ & $6,41.10^{5}$ & 2,365 \\
\hline Batang VTOL & $3,898.10^{7}$ & $8,67.10^{8}$ & 21.242 \\
\hline Stringer atas & $4,719.10^{7}$ & $8,67.10^{8}$ & 17,373 \\
\hline Stringer bawah & $3,432.10^{7}$ & $8,67.10^{8}$ & 24,262 \\
\hline Engine mount depan & $2,077.10^{5}$ & $1,33.10^{7}$ & 63,035 \\
\hline Engine mount belakang & $2,077.10^{5}$ & $1,33.10^{7}$ & 63,035 \\
\hline
\end{tabular}

\subsection{Analisis struktur Tail Assembly pada kondisi beban terbang jelajah}

Pada kondisi terbang jelajah tail akan mengalami gaya ke bawah akibat kesetimbangan momen pitch yang terjadi pada sayap. Pemodelan beban diterapkan pada horizontal stabilizer ke bawah sebesar 2,43N, clamp diletakkan pada ujung tailboom.

Nilai tegangan maksimum terjadi pada stringer horizontal $6,865.10^{7} \mathrm{~Pa}$ (gambar 7), hal ini terjadi karena elemen terdekat yang menahan beban lebih besar adalah stringer horizontal yang memiliki bentuk persegi panjang (lebar $1 \mathrm{~mm}$, tinggi $5 \mathrm{~mm}$ ) dibandingkan tailboom memiliki diameter yang lebih besar $16 \mathrm{~mm}$, meskipun momen terbesar terjadi pada ujung batang tailboom yang di clamp. Nilai defleksi maksimum terjadi pada bagian vertikal tail sebesar 26, $5 \mathrm{~mm}$. 


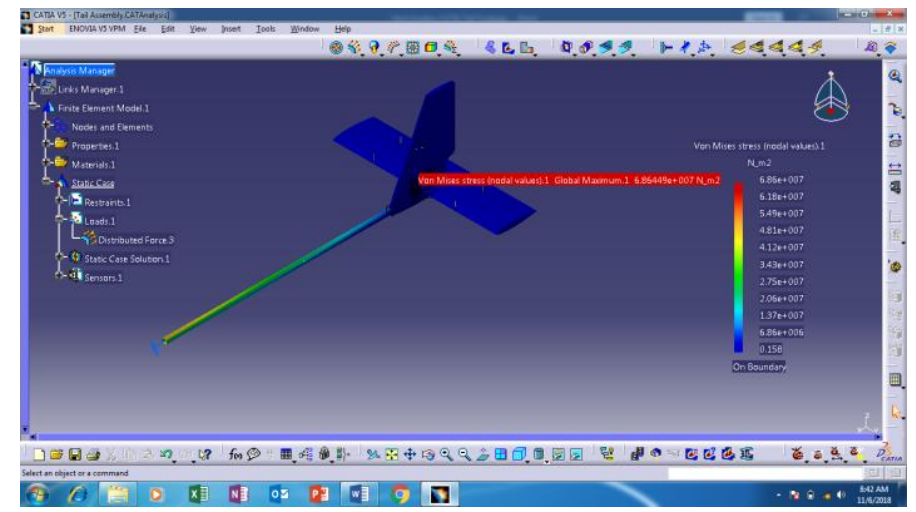

Gambar 7. Tegangan maksimum Von mises pada tail assembly

Tabel 5. Nilai tegangan maksimum dan $M S$ kondisi beban terbang jelajah pada tail

\begin{tabular}{|l|c|c|c|}
\hline \multicolumn{1}{|c|}{ Part } & $\begin{array}{c}\text { Tegangan } \\
\text { Maksimum (Pa) }\end{array}$ & $\begin{array}{c}\text { Yield } \\
\text { Strength }(\mathbf{P a})\end{array}$ & Margin of Safety \\
\hline Tailboom & $5,549.10^{7}$ & $8,67.10^{8}$ & 14,624 \\
\hline Horisontal Stabilizer & $1,086.10^{5}$ & $6,41.10^{5}$ & 4,902 \\
\hline Vertical Stabilizer & $8,131.10^{4}$ & $6,41.10^{5}$ & 6,883 \\
\hline Stringer Horisontal & $6,865.10^{7}$ & $8,67.10^{8}$ & 11,629 \\
\hline Stringer Vertical & $5.770 .10^{5}$ & $8,67.10^{8}$ & 1501,6 \\
\hline
\end{tabular}

\section{Kesimpulan}

Dari hasil analisis yang dilakukan pada penelitian rancangan pesawat UAV Fixed Wing VTOL, dapat disimpulkan sebagai berikut:

1. Proses perancangan pesawat UAV VTOL dilakukan melalui tahap-tahap menentukan DR\&O, penentuan konfigurasi, menentukan perkiraan berat pesawat, melakukan geometri sizing, melakukan pemodelan 3D dan analisis struktur menggunakan software Catia V5R21.

Adapun hasil rancangan konfigurasi dan geometri pesawat adalah sebagai berikut:

Konfigurasi Pesawat:

\begin{tabular}{|l|l|}
\hline Komponen & Konfigurasi \\
\hline Wing & Rectangular, High wing \\
\hline Tail & Conventional \\
\hline Power plant & Pusher \\
\hline
\end{tabular}

Geometri Pesawat:

\begin{tabular}{|l|c|}
\hline Komponen Utama & Dimensi \\
\hline Fuselage length $(l)$ & $1,32 \mathrm{~m}$ \\
\hline Wing Area $\left(S_{W}\right)$ & $0,419257 \mathrm{~m}^{2}$ \\
\hline Wing Span $\left(\mathrm{b}_{\mathrm{W}}\right)$ & $1,713125 \mathrm{~m}$ \\
\hline Vertical Tail Area $\left(S_{V T}\right)$ & $0,033258 \mathrm{~m}^{2}$ \\
\hline Vertical Tail Span $\left(b_{V T}\right)$ & $0,234254 \mathrm{~m}$ \\
\hline Horizontal Tail Area $S_{H T}$ & $0,059389 \mathrm{~m}^{2}$ \\
\hline Horizontal Tail Span $b_{H T}$ & $0,487395 \mathrm{~m}$ \\
\hline
\end{tabular}

2. Pada kasus beban terbang jelajah tegangan maksimum terjadi pada stringer bagian bawah dengan nilai $6,355.10^{7} \mathrm{~Pa}$, sedangkan pada pembebanan vertikal take off terjadi pada stringer bagian atas sebesar $4,719.10^{7} \mathrm{~Pa}$. Untuk beban pada tail nilai tegangan maksimum $6,865 \cdot 10^{7} \mathrm{~Pa}$ terjadi pada stringer horizontal.

Berdasarkan nilai keseluruhan margin of safety struktur pesawat UAV Fixed Wing VTOL 
dinyatakan aman karena semua nilainya positif.

\section{Ucapan Terimakasih}

Atas terlaksananya penelitian ini penulis mengucapkan terima kasih kepada Sekolah Tinggi Teknologi Adisutjipto yang telah memberikan dukungan finansial serta fasilitasnya.

\section{Daftar Pustaka}

[1] Patra, Aswini Kumar, Patel, Kandarp, Bundela, Gourav Singh, Vinay. P. (2017). Design and Development of Transition Autopilot for VTOL UAV, International Journal of Innovations In Engineering Research and Technology (IJIERT), Vol. 4, Issue 6.

[2] Sandilya, B. Vijay, Kumar K, Sachin, Kumar P., Sampath, Shyam Y, Santosh. (2014). Design And 3D Modelling Of Vertical Take Off And Landing (VTOL) Tilt Quad Rotor RC Aircraft, Proceedings of 5th SARC-IRF International Conference, Bangalore, India.

[3] Raymer, D. P. (1999). Aircraft design: a conceptual approach, American Institute of Aeronautics and Astronautics. Inc., Reston, VA, 21.

[4] Niu, M. C. Y. (1997). Airframe stress analysis and sizing (p. 795). Hong Kong: Conmilit Press.

[5] Australia, C. A. S. A. (2000). Design Standards: Unmanned Aerial vehicles-Aeroplane.

[6] Kamil, Sulaeman, Beban Pesawat, Penerbit ITB. 